\title{
Managing risk by the weakest link: Are we training effectively in the heat?
}

\author{
Andrew P Hunt ${ }^{1 *}$, Joanne N Caldwell ${ }^{2}$, Daniel C Billing ${ }^{1}$, Mark J Patterson ${ }^{1}$ \\ From 15th International Conference on Environmental Ergonomics (ICEE XV) \\ Portsmouth, UK. 28 June - 3 July 2015
}

\section{Introduction}

The Australian Army Working in Heat policy dictates limits to physical work duration to minimise the risk of heat casualties. However, commanders suggest that strict adherence to the policy prevents the majority of personnel from engaging in physical training to the limits that are physiologically tolerable in the heat. Therefore, this study examined the heat strain of personnel performing a common military activity (forced march) in environmental conditions close to the policy limits. The aim was to determine the proportion of personnel at risk of becoming heat casualties.

\section{Methods}

Thirty-seven Royal Australian Infantry soldiers volunteered to participate in a march of up to $10 \mathrm{~km}$. Participants wore a standard combat uniform and boots while carrying $40 \mathrm{~kg}$ of military equipment. The participants commenced the march in a rested thermoneutral state (5:30 am) after having ingested a temperature sensor at least $7 \mathrm{~h}$ prior. The pace of the march was guided by timing feedback at $2.5 \mathrm{~km}$ intervals to maintain a pace of $\sim 5.5 \mathrm{~km} . \mathrm{h}^{-1}$. The wet-bulb globe temperature (WBGT) rose through the range $21-26{ }^{\circ} \mathrm{C}$ over the course of the march, averaging $23.1(1.8){ }^{\circ} \mathrm{C}$, which spanned the policy limit $\left(22^{\circ} \mathrm{C}\right)$ for this combination of protective clothing attire and work intensity. Participants rated the severity of environmental symptoms pertinent to work in the heat after the march [1].

\section{Results}

Twenty-three (62\%) participants completed the march in 107(6.4) min (Completers). Nine (24\%) participants were

\footnotetext{
* Correspondence: hunt2@dsto.defence.gov.au

${ }^{1}$ Land Division, Defence Science and Technology Organisation, Melbourne, Australia

Full list of author information is available at the end of the article
}

symptomatic for heat exhaustion and withdrew from the march after 71.6(10.1) min (Symptomatic). Five (14\%) participants were removed from the march when their intestinal temperature rose above $39.0^{\circ} \mathrm{C}$ (Hyperthermic; Figure 1), which occurred after 58.4(4.5) min. The Symptomatic group reported significantly higher sum of environmental symptoms severity: 28(12); compared to the Completers: $12(8), P=0.06$; and the Hyperthermic: 13(10), $P=0.029$.

\section{Discussion}

Working in the heat, up to and above the recommended limitations, revealed that the policy limits coincide with a proportion of personnel at risk of becoming heat casualties. However, the findings also show that the majority of

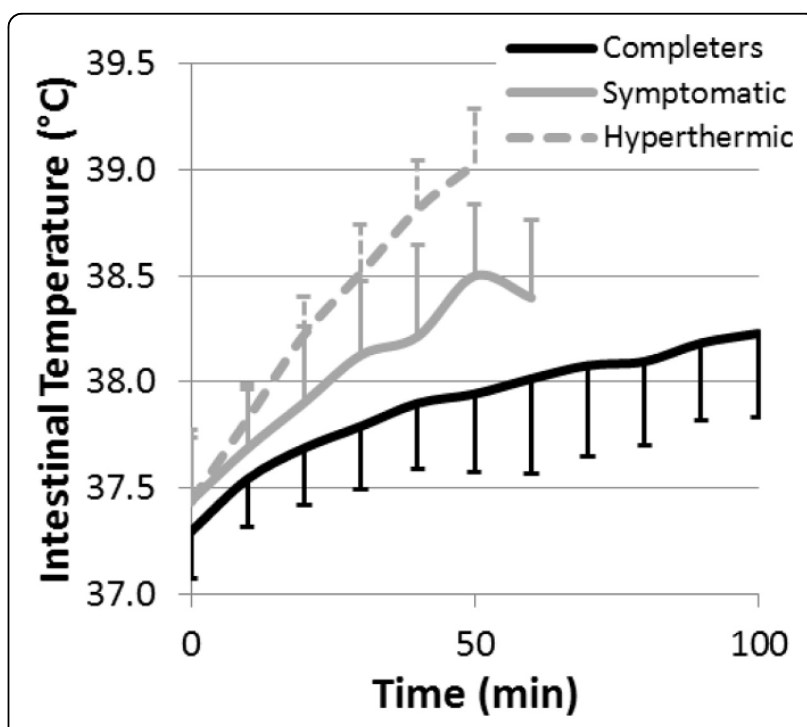

Figure 1 Intestinal temperature during the march for the completers, symptomatic, and hyperthermic. 
personnel did not experience excessive heat strain that would endanger health or impair performance.

\section{Conclusion}

The current Australian Army Working in Heat Policy is an effective risk management strategy to highlight work activities which will expose a portion of personnel to excessive heat strain. However, further research is required to better inform military commanders on strategies to safely and effectively train all personnel for the rigours of physically demanding work in hot environments.

\section{Authors' details}

${ }^{1}$ Land Division, Defence Science and Technology Organisation, Melbourne, Australia. ${ }^{2}$ Centre for Human and Applied Physiology, University of

Wollongong, Wollongong, Australia.

Published: 14 September 2015

\section{Reference}

1. Sampson JB, Kobrick $J$, Johnson RF: Measurement of subjective reactions to extreme environments: The environmental symptoms questionnaire. Military Psychology 1994, 6(4):215-233.

doi:10.1186/2046-7648-4-S1-A101

Cite this article as: Hunt et al:: Managing risk by the weakest link: Are we training effectively in the heat? Extreme Physiology \& Medicine 2015 4(Suppl 1):A101.
Submit your next manuscript to BioMed Central and take full advantage of:

- Convenient online submission

- Thorough peer review

- No space constraints or color figure charges

- Immediate publication on acceptance

- Inclusion in PubMed, CAS, Scopus and Google Scholar

- Research which is freely available for redistribution

Submit your manuscript at www.biomedcentral.com/submit 